\title{
PENGARUH PERCEIVED QUALITY DAN PERCEIVED VALUE \\ TERHADAP BRAND LOYALTY MELALUI \\ CUSTOMER SATISFACTION J-KLIN BEAUTY JEMBER
}

\section{EFFECT OF PERCEIVED QUALITY AND PERCEIVED VALUE TOWARDS BRAND LOYALTY THROUGH CUSTOMER SATISFACTION J-KLIN BEAUTY JEMBER}

Anton Yuliansyah ${ }^{1}$, Timotius Dwi Handoko ${ }^{2}$

Universitas Moch Sroedji Jember ${ }^{1,2}$

yuliansyah.anton@yahoo.com ${ }^{1}$

Submit,23-02-2019 Accepted,03-05-2019 Publish,08-05-2019

\section{ABSTRACT}

Consumers play a very important role in providing an assessment of the quality of services obtained from service companies. This study aims to determine the effect of variable perceived quality and perceived value on the formation of brand loyalty through customer satisfaction of J-Klin customers in Jember Beauty Data used in this study is primary data. Data processing method uses path analysis method with the help of SPSS 24 analysis tool. The results of the study show that variable perceived quality and perceived value and customer satisfaction affect the formation of brand loyalty in $J$ Klin Beauty Jember customers either directly or indirectly

Keywords: Perceived Quality, Perceived Value, Customer Satisfaction, Brand Loyalty

\begin{abstract}
ABSTRAK
Konsumen memegang peranan yang sangat penting dalam memberikan penilaian terhadap kualitas jasa yang didapat dari perusahaan jasa. Penelitian ini bertujuan untuk mengetahui pengaruh Variabel perceived quality dan perceived value terhadap pembentukan brand loyalty melalui customer satisfaction pelanggan J-Klin Beauty Jember Data yang digunakan dalam penelitian ini berupa data primer. Metode pengolahan data menggunakan metode analisis jalur dengan bantuan alat analisis SPSS 24. Hasil penelitian menunjukkan bahwa Variabel perceived quality dan perceived value serta customer satisfaction berpengaruh terhadap pembentukan brand loyalty pada pelanggan J-Klin Beauty Jember baik secara langsung ataupun tidak langsung
\end{abstract}

Kata Kunci: Perceived Quality, Perceived Value, Customer Satisfaction, Brand Loyalty

\section{PENDAHULUAN}

Semakin

berkembangnya

perekonomian global sekarang ini mendorong pertumbuhan sektor jasa semakin meningkat. Sektor ini merupakan yang tumbuh paling cepat bila dibandingkan dengan sektor jasa lainnya. Perkembangan dan peranan sektor jasa yang semakin besar di masa mendatang terutama didorong oleh kemajuan pesat dalam teknologi telekomunikasi dan informasi. Faktor 
yang menentukan keberhasilan perusahaan jasa adalah kemampuan perusahaan dalam memberikan pelayanan yang berkualitas kepada konsumennya. Suatu kualitas pelayanan jasa disebut baik apabila penyedia jasa dapat memberikan pelayanan sesuai ataupun melebihi harapan konsumen. Kualitas jasa merupakan tingkat keunggulan yang diharapkan serta pengendalian atas tingkat keunggulan tersebut untuk memenuhi keinginan atau harapan konsumen.

Konsumen memegang peranan yang sangat penting dalam memberikan penilaian terhadap kualitas jasa yang didapat dari perusahaan jasa. Jika kenyataan melebih dari yang diharapakan, maka pelayanan dapat dikatakan baik, sedangkan jika kenyataan kurang dari yang diharapkan, maka layanan dikatakan tidak baik. Apabila kenyataan sama dengan yang diharapkan, maka pelayanan disebut memuaskan. Dengan demikian kualitas jasa (service quality) dapat diartikan seberapa jauh perbedaan antara kenyataan dengan harapan pelanggan atas layanan yang mereka terima/peroleh (Lupiyoadi, 2001).

Persaingan bisnis jasa kecantikan sekarang ini semakin ketat. Persaingan terlihat dengan semakin banyak bermunculan klinik-klinik kecantikan baru. Mereka saling berlomba dengan melakukan inovasi-inovasi baru dalam memberikan pelayanan prima untuk memberikan kepuasan optimal pada konsumen. J-Klin Beauty Jember Merupakan klinik perawatan dan kecantikan kulit menggunakan teknologi dan produk terbaru yang aman dan telah terbukti hasilnya. J-Klin Beauty Clinic berkembang dari ide, pembelajaran dan pengalaman. Kami menghadirkan alat terbaru dalam dunia perawatan dan kecantikan kulit. Kami juga menggunakan produk-produk perawatan dan kecantikan kulit dari bahan alamiah dengan lisensi Paris. JKlin Beauty Clinic telah hadir di kota Jember tepatnya di Jl. Melati no.5 Jember telp. 0331-4069565. Kami memberi layanan perawatan tubuh dan kecantikan wajah. Didukung dengan treatment terbaru dengan ataupun tanpa alat kecantikan yang telah teruji hasilnya. Semua treatment dan produk yang ada atas pengawasan dokter. Pelayanan treatment juga dilakukan oleh dokter maupun beautician yang berpengalaman

Persepsi terhadap kualitas dapat membantu konsumen untuk memiliki penilaian subjektif tentang keseluruhan kualitas produk yang membuat produk terus terdiferensiasi, menonjol dan menjadi merek selektif dalam Pikiran konsumen (Chi et al., 2009). Persepsi dari seluruh kualitas dari suatu produk atau jasa dapat dari nilai suatu produk atau jasa tersebut serta dapat berpengaruh baik secara langsung terhadap keputusan pembelian konsumen (Durianto et al., 2001).

Loyalitas suatu merek yaitu ukuran serta keterkaitan pelanggan kepada sebuah merek. Ukuran tentang loyalitas kemamampuan dalam memberikan gambaran tentang kemungkinan seorang pelanggan beralih kemerek produk lain, terutama jika merek tersebut terdapat perubahan, baik menyangkut harga maupun atribut lain yang terdapat pada merek tersebut (Durianto et al., 2001)

Studi empiris Welly Hartono (2016) dengan judul Pengaruh Perceived Quality, Perceived Value dab Service Quality Terhadap Customer Satisfaction Dan Brand Loyality Pada STARBUCK COFFEE DI SURABAYA. Menyimpulkan bahwa Hasil dari penelitian ini bahwa semua variabel independen (persepsi kualitas, persepsi nilai, dan kualitas layanan) 
mempunyai pengaruh signifikan terhadap kepuasan konsumen dan variabel intervening (kepuasan konsumen) mempunyai pengaruh signifikan terhadap loyalitas merek.

Brand loyalty adalah loyalitas konsumen yang secara konsisten melakukan pembelian pada satu merek yang sama dengan produk yang spesifik atau kategori pelayanan tertentu. Menurut Mohammad, 2012 indikator brand loyalty adalah :

1. Pemenuh kebutuhan pelanggan akan produk

2. Memiliki nilai pembelian yang tinggi

3. Menginformasikan hal-hal positif

4. Pantas direkomendasikan pada orang lain

5. Sebagai pilihan pertama di perawatan kecantikan yang akan datang

Menurut Kotler

satisfaction atau kepuasan adalah perasaan seseorang baik senang ataupun kecewa, yang dihasilkan dari kinerja produk yang dirasakan (atau hasil) dengan ekspetasi yang diharapkan. Jika kinerja jauh dari harapannya, maka konsumen tidak puas. Jika kinerja sama atau sesuai dengan harapan yang diinginkan, maka konsumen akan merasa puas. Jika kinerja melebihi harapan dari konsumen/pelanggan, pelanggan akan merasa sangat puas atau senang. Dari definisi ini, dapat dikatakan bahwa kepuasan adalah perasaan yang timbul dari sesorang baik senang atau kecewa terhadap produk yang ditawarkan dengan ekspetasi yang diharapkan.

Berdasarkan kerangka

definisional yang disusun oleh Giese dan Cote (2000) yang dikutip dalam buku Tjiptono dan Chandra (2011), kepuasan pelanggan adalah angkuman berbagai intensitas respon aktif. Tipe respon efektif yang mungkin dialami konsumen harus didefinisikan secara detail oleh peneliti, sebagaimana konteks dalam penelitiannya.

Hal yang dapat mempengaruhi kepuasan pelanggan dapat dilihat dari ukuran atau dimensi kepuasan pelanggan menurut Kotler (2002), yaitu : Tetap setia, Membeli produk yang ditawarkan, Merekomendasikan produk, Bersedia membayar lebih dan memberi masukan

Menurut Hill, Brierley \& MaDougall yang dikutip buku Tjiptono (2004), kepuasan pelanggan adalah ukuran kinerja "produk total" sebuah organisasi dibandingkan dengan serangkaian keperluan dari pelanggan (customer requirements). Prinsip dasar yang penting dalam pengukuran kepuasan pelanggan adalah "doing best what matters most to customers" (melakukan aspek - aspek yang terbaik, terpenting bagi pelanggan)"

Suatu nilai yang dirasakan (perceived value) dari suatu akibat atau keuntungan yang pelanggan terima yang kaitannya dengan total seluruh biaya (termasuk didalamnya adalah harga yang dibayarkan ditambah biayabiaya lain terkait dengan pembelian) Syamsiah, 2009. Menurut Mohammad, 2012 indikator perceived value adalah: 1) kelayakan, 2) harga yang pantas, 3) menawarkan nilai yang baik, 4) kesesuaian harga dengan produk

Pentingnya perceived value dalam pemasaran, maka banyak peneliti yang meneliti apa saja faktor yang dapat menentukan perceived value yang dirasakan oleh konsumen (Dodds et al., 1991). Di antara faktor penentu tersebut, isyarat ekstrinsik dan persepsi kualitas mendapat banyak perhatian di antara peneliti pemasaran sebagai penentu persepsi nilai.

Sedangkan menurut Canon et al. (2008) nilai pelanggan adalah 
"perbedaan antara manfaat yang dilihat seseorang pelanggan dari suatu penawaran pasar serta biaya untuk mendapatkan manfaat tersebut. Dari beberapa pengertian di atas dapat disimpulkan bahwa perceived value adalah perbedaan antara penilaian prospektif manfaat apa yang diterima dan biaya yang dikeluarkan oleh konsumen terhadap suatu produk.

Terdapat empat dimensi yang diberikan oleh perusahaan kepada pelanggan yaitu :

1. Nilai ekonomi. Nilai ekonomi berhubungan dengan manfaat ekonomi yang pelanggan rasakan saat menggunakan suatu barang atau jasa dari suatu perusahaan dibandingkan dengan biaya yang telah mereka keluarkan.

2. Nilai fungsional. Nilai fungsional berhubungan dengan performa atau kinerja dari suatu barang atau jasa.

3. Nilai Emosional. Nilai emosional berhubungan dengan perasaan yang dirasakan saat pelanggan menggunakan jasa atau barang dari suatu perusahaan.

4. Nilai Sosial. Berhubungan dengan kemampuan barang atau jasa dari suatu perusahaan untuk meningkatkan self concept saat menggunakan barang atau jasa dari suatu perusahaan.

Sedangkan menurut Sweeny dan Soutar dalam Tjiptono (2004) indikator customer perceived value terdiri dari 4 aspek utama, yaitu :

1. Emotional value, yaitu manfaat yang diperoleh dari perasaan atau afektif/emosi positif yang ditimbulkan dari mengkonsumsi produk.

2. Social value, yaitu kegunaan yang didapatkan dari produk untuk meningkatkan konsep diri sosial konsumen.
3. Quality/performance value, yakni utilitas yang didapatkan dari produk dikarenakan reduksi biaya jangka pendek dan biaya jangka panjang.

4. Price/value of money, yakni utilitas yang diperoleh dari persepsi terhadap kualitas dan kinerja yang diharapkan atas produk.

Menurut Parasuraman et al., (1988) perceived quality adalah kualitas yang mempersepsikan penilaian konsumen tentang keunggulan produk secara keseluruhan dan keunggulan bukan kualitas yang sebenarnya dari produk (Wang and Tsai, 2014). Perceived quality didefinisikan sebagai cara pelanggan memandang ekuitas merek produk dan keunggulan keseluruhan dibandingkan dengan alternatif yang tersedia. (Beneke et al., 2013). Berdasarkan pengertian di atas maka dapat disimpulkan bahwa perceived quality dapat dikatakan sebagai suatu penilaian konsumen tentang keunggulan suatu produk dan jasa secara keseluruhan dengan membandingkan alternatif yang tersedia.

Menurut David Garvin dalam Gaspersz (2001) indikator perceived quality sebagai berikut :

1. Performance, yaitu berhubungan dengan aspek fungsional dari produk itu sendiri serta suatu karakter utama pelanggan yang dipertimbangkan ketika membeli suatu produk.

2. Features merupakan aspek kedua dari performasi yang menambah dari fungsi dasar yang berkaitan dengan pilihan-pilihan dan pengembangannya.

3. Reliability, yaitu berkaitan dengan probabilitas atau kemungkinan suatu produk malaksanakan fungsinya secara berhasil dalam periode tertentu dan dalam kondisi tertentu. 
4. Comformance, yaitu berkaitan dengan tingkat kesesuaian produk terhadap spesifikasi yang telah ditetapkan sebelumnya berdasarkan keinginan pelanggan.

5. Durability merupakan suatu ukuran masa pakai dari suatu produk. Durability berkaitan dengan daya tahan dari produk.

6. Serviceability merupakan karakteristik yang berkaitan dengan kecepatan, keramahan/kesopanan, kompetensi, kemudahan serta akurasi dalam perbaikan.

7. Aesthetic merupakan karakteristik yang bersifat subyektif sehingga berkaitan dengan pertimbangan pribadi dan refleksi dari preferensi atau pilihan individu.

8. Perceived Quality, yaitu bersifat subyektif berkaitan dengan perasaan pelanggan dalam mengkonsumsi produk itu.

\section{METODE PENELITIAN}

Penelitian ini mengambil objek pelanggan J-Klin Beauty Jember. Sedangkan waktu penelitian pada bulan September sampai dengan Desember 2018. Populasi dalam penelitian ini adalah seluruh pelanggan J-Klin Beauty Jember. Jumlah sampel pada penelitian ini mengacu pada pendapat Sugiyono (2008) bahwa jumlah sampel minimal 10 kali dari jumlah variabel yang dinilai. Dalam penelitian ini variabel yang digunakan sebanyak 4 variabel, yaitu Brand Loyalty Customer Satisfaction Perceived Value dan Perceived Quality. Dengan demikian sampel yang akan diambil dalam penelitian ini berjumlah 40 responden. Kriteria utama pemilihan sampel di dalam penelitian ini adalah pelanggan JKlin Beauty Jember. Metode penentuan sampel yang digunakan dalam penelitian ini adalah accidental sampling, dengan alasan jumlah populasi yang terlalu besar. Metode accidental sampling melakukan pengambilan sampel secara acak tanpa memperhatikan kriteria sampel apapun sampai jumlah responden yang diinginkan terpenuhi.

Penelitian ini menggunakan penelitian deskriptif dengan pendekatan kuantitatif. Metode dari Penelitian Kuantitatif Menurut Sugiyono (2008) Metode penelitian yang berlandas pada filsafat positif, digunakan untuk penelitian pada populasi atau sampel tertentu, pengumpulan data dengan menggunakan instrumen penelitian, analisis data bersifat statistik atau kuantitatif, dengan tujuan untuk menguji hipotesis yang telah ditetapkan. Identifikasi variabel meliputi Variabel Terikat (Brand Loyalty), Variabel Interving (Customer Satisfaction) dan Variabel Bebas (Perceived Value dan Perceived Quality)

Metode analisis data meliputi; 1) uji instrumen terdiru dari uji validitas dan uji reliabilitas, 2) uji ekonometrik (Asumsi Klasik) meliputi (Uji Normalitas, Uji Multikolinearitas, Uji Heteroskedastisitas, Uji Autokorelasi, dan 3) Analisis Jalur

\section{HASIL DAN PEMBAHASAN \\ Pengujian Instrumen Uji Validitas \\ Tabel 1. Hasil Uji Validitas}

\begin{tabular}{|c|c|c|c|c|}
\hline No & Variabel & $\begin{array}{c}\text { Item } \\
\text { Pernyataan } \\
\end{array}$ & $\begin{array}{c}\mathbf{r} \\
\text { hitung }\end{array}$ & Ket. \\
\hline 1 & X1 & $\begin{array}{l}\mathrm{X} 1.1 \\
\mathrm{X} 1.2 \\
\mathrm{X} 1.3\end{array}$ & $\begin{array}{l}0,574 \\
0,663 \\
0,722 \\
\end{array}$ & $\begin{array}{c}\text { Valid } \\
\text { r }>0,291\end{array}$ \\
\hline 2 & $\mathrm{X} 2$ & $\begin{array}{l}\mathrm{X} 2.1 \\
\mathrm{X} 2.2 \\
\mathrm{X} 2.3 \\
\end{array}$ & $\begin{array}{l}0,826 \\
0,794 \\
0,642\end{array}$ & $\begin{array}{c}\text { Valid } \\
\text { r }>0,291\end{array}$ \\
\hline 3 & Z & $\begin{array}{l}\mathrm{Z} 1 \\
\mathrm{Z} 2 \\
\mathrm{Z} 3\end{array}$ & $\begin{array}{l}0,786 \\
0,850 \\
0,623\end{array}$ & $\begin{array}{c}\text { Valid } \\
\text { r }>0,291\end{array}$ \\
\hline 4 & $\mathrm{Y}$ & $\begin{array}{l}\text { Y1 } \\
\text { Y2 } \\
\text { Y3 }\end{array}$ & $\begin{array}{l}0,565 \\
0,797 \\
0,593\end{array}$ & $\begin{array}{c}\text { Valid } \\
\text { r }>0,291\end{array}$ \\
\hline
\end{tabular}


Berdasarkan tabel 1 dapat diketahui bahwa masing-masing indikator yang digunakan mempunyai nilai-nilai $r$ hitung yang lebih besar dari 0,291. Berarti seluruh indikator yang digunakan dalam variabel penelitian ini layak digunakan sebagai pengumpulan data.

\section{Uji Reliabilitas}

Tabel 2. Hasil Uji Reliabilitas

\begin{tabular}{cccc}
\hline No & Variabel & $\begin{array}{c}\text { Nilai } \\
\text { Alpha(a) }\end{array}$ & Keterangan \\
\hline 1 & $\mathrm{X} 1$ & 0,656 & $\begin{array}{c}\text { Reliabel > } \\
0,60\end{array}$ \\
\hline 2 & $\mathrm{X} 2$ & 0,629 & $\begin{array}{c}\text { Reliabel > } \\
0,60\end{array}$ \\
\hline 3 & $\mathrm{Z}$ & 0,677 & $\begin{array}{c}\text { Reliabel }> \\
0,60\end{array}$ \\
\hline 4 & $\mathrm{Y}$ & 0,781 & $\begin{array}{c}\text { Reliabel }> \\
0,60\end{array}$ \\
\hline & Berdasarkan tabel & 2 & diatas,
\end{tabular}

menunjukkan hasi koefisien keandalan reliabilitas untuk variable $\mathrm{X} 1, \mathrm{X} 2, \mathrm{X} 3$, $\mathrm{Z}$ dan $\mathrm{Y}$ dalam anallisis berada pada kreteria tinggi dan sangat tinggi. Hal ini berarti bahwa item pernyataan yang digunakan akan mampu memperoleh data yang konsisten dalam arti bahwa apabila pertanyaan tersebut diajukan lagi akan diperoleh jawaban yang relative sama dengan jawaban pertama.Sehingga dapat dikatakan bahwa semua variable adalah reliable karena nilai koefisien reliable lebih besar dari 0,6.

\section{Uji Asumsi Klasik}

Uji Normalitas

Tabel 3. Hasil Uji Normalitas Untuk Persamaan Pertama

\begin{tabular}{llr}
\hline & & \multicolumn{1}{c}{ Residual } \\
\hline $\mathrm{N}$ & & 40 \\
\hline Normal Parameters $^{\mathrm{a}}$ & Mean & .0004 \\
\hline & $\begin{array}{l}\text { Std. } \\
\text { Deviation }\end{array}$ & 1.21275 \\
\hline $\begin{array}{l}\text { Most Extreme } \\
\text { Differences }\end{array}$ & Absolute & .168 \\
\hline & Positive & .084 \\
\hline & Negative & -.170 \\
\hline $\begin{array}{l}\text { Kolmogorov- } \\
\text { Smirnov Z }\end{array}$ & & 1.222 \\
\hline
\end{tabular}

\begin{tabular}{l}
\hline $\begin{array}{l}\text { Asymp. Sig. (2- } \\
\text { tailed) }\end{array}$ \\
\hline Berdasarkan tabel 3 diatas, asumsi \\
kenornalan nilai residual pada model 1 \\
perlu diuji untuk membuktikan apakah \\
nilai residual berada disekitar nilai nol. \\
Hasil uji dengan kolmogrov-Smirnov \\
membuktikan bahwa nilai residual pada \\
model 1 mengikuti sebaran normal. Hal \\
ini dibuktikan dengan hasil Asymp. $(2-$ \\
tailed) > 0,05 Nilai residual yang \\
diperoleh adalah 0,077 karena nilai \\
residual untuk 2 tailed $>0,05$ sehingga \\
data dapat dikatakan memenuhi asumsi \\
normalitas karena nilainya $>0,05$.
\end{tabular}

Tabel 4. Hasil Normalitas Untuk Persamaan Kedua

\begin{tabular}{llr}
\hline & & \multicolumn{2}{c}{ Residual } \\
\hline $\mathrm{N}$ & & \multicolumn{1}{c}{40} \\
\hline $\begin{array}{l}\text { Normal } \\
\text { Parameters }^{\mathrm{a}}\end{array}$ & Mean & .0017 \\
\hline & $\begin{array}{l}\text { Std. } \\
\text { Deviation }\end{array}$ & 1.21151 \\
\hline $\begin{array}{l}\text { Most Extreme } \\
\text { Differences }\end{array}$ & Absolute & .054 \\
\hline & Positive & .062 \\
\hline $\begin{array}{l}\text { Kolmogorov- } \\
\text { Smirnov Z }\end{array}$ & Negative & -.079 \\
\hline $\begin{array}{l}\text { Asymp. Sig. } \\
\text { (2-tailed) }\end{array}$ & & .691 \\
\hline
\end{tabular}

Berdasarkan tabel 4 diatas, asumsi kenornalan nilai residual pada model 2 perlu diuji untuk membuktikan apakah nilai residual berada disekitar nilai nol. Hasil uji dengan kolmogrov-Smirnov membuktikan bahwa nilai residual pada model 1 mengikuti sebaran normal. Hal ini dibuktikan dengan hasil Asymp.(2tailed) > 0,05. Nilai residual yang diperoleh adalah 0,759 karena nilai residual untuk 2 tailed $>0,05$ sehingga data dapat dikatakan memenuhi asumsi normalitas karena nilainya $>0,05$.
Analisis Jalur (Path Analysis)
Pengaruh Variabel Perceived Quality (X1) terhadap Customer Satisfaction (Z) 
Berdasarkan tabel dapat dilihat nilai beta $(\beta)$, t-hitung dan signifikansi tnya. Perhitungan dengan analisis jalur (path analysis) pada tingkat kepercayaan $5 \%$, diperoleh nilai beta $(\beta)$ sebesar 0,801 dengan signifikansi $t$ sebesar 0,030. Karena nilai signifikansi $\mathrm{t}<\alpha$ atau $0,035<0,05$ maka hipotesis tersebut ditolak. Dengan demikian ada pengaruh signifikan Perceived Quality terhadap Customer Satisfaction. Perceived quality didefinisikan sebagai cara pelanggan memandang ekuitas merek produk dan keunggulan keseluruhan dibandingkan dengan alternatif yang tersedia. (Beneke et al., 2013). Berdasarkan pengertian di atas maka dapat disimpulkan bahwa perceived quality dapat dikatakan sebagai suatu penilaian konsumen tentang keunggulan suatu produk dan jasa secara keseluruhan dengan membandingkan alternatif yang tersedia. Semakin baik perceived quality yang dimiliki suatu produk maka semakin meningkatkan kepuasan pelanggan.

\section{Pengaruh Variabel Perceived Value} (X2) terhadap Customer Satisfaction (Z)

Berdasarkan tabel dapat dilihat nilai beta $(\beta)$, t-hitung dan signifikansi tnya. Perhitungan dengan analisis jalur (path analysis) pada tingkat kepercayaan $5 \%$, diperoleh nilai beta $(\beta)$ sebesar 0,544 dengan signifikansi $t$ sebesar 0,000. Karena nilai signifikansi $\mathrm{t}<\alpha$ atau $0,000<0,05$ maka hipotesis tersebut ditolak. Dengan demikian ada pengaruh signifikan Perceived Value terhadap Customer Satisfaction. Menurut Canon et al. (2008) nilai pelanggan adalah perbedaan antara manfaat yang dilihat seseorang pelanggan dari suatu penawaran pasar serta biaya untuk mendapatkan manfaat tersebut. Untuk itu ketika nilai pelanggan meningkat maka akan meningkatkan kepuasan pelanggan.

\section{Pengaruh Variabel Perceived Quality} (X1) terhadap Brand Loyalty (Y)

Berdasarkan tabel dapat dilihat nilai beta $(\beta)$, t-hitung dan signifikansi tnya. Perhitungan dengan analisis jalur (path analysis) pada tingkat kepercayaan 5\%, diperoleh nilai beta $(\beta)$ sebesar 0,406 dengan signifikansi t sebesar 0,020. Karena nilai signifikansi $\mathrm{t}<\alpha$ atau $0,027<0,05$ maka hipotesis tersebut ditolak. Dengan demikian ada pengaruh signifikan Perceived Quality terhadap Brand Loyalty. Semakin baik Perceived Quality maka loyalitas pelanggan terhadap suatu brand akan semakin meningkat. Keterikatan pelanggan terhadap suatu brand loyalty akan mengikat pelanggan agar tidak berpindah ke brand lain.

Pengaruh Variabel Perceived Value (X2) terhadap Brand Loyalty (Y)

Berdasarkan tabel dapat dilihat nilai beta $(\beta)$, t-hitung dan signifikansi tnya. Perhitungan dengan analisis jalur (path analysis) pada tingkat kepercayaan 5\%, diperoleh nilai beta $(\beta)$ sebesar 0,361 dengan signifikansi t sebesar 0,022. Karena nilai signifikansi $\mathrm{t}<\alpha$ atau 0,022 <0,05 maka hipotesis tersebut ditolak. Dengan demikian ada pengaruh signifikan Perceived Value terhadap Brand Loyalty.

\section{Pengaruh Variabel Customer Satisfaction (Z) terhadap Brand Loyalty (Y)}

Berdasarkan tabel dapat dilihat nilai beta $(\beta)$, t-hitung dan signifikansi tnya. Perhitungan dengan analisis jalur (path analysis) pada tingkat kepercayaan $5 \%$, diperoleh nilai beta $(\beta)$ sebesar 0,295 dengan pvalue sebesar 0,042. Karena nilai signifikansi $\mathrm{t}<\alpha$ atau $0,042<0,05$ maka hipotesis tersebut ditolak. Dengan demikian ada pengaruh signifikan Customer Satisfaction terhadap Brand Loyalty. 
Hal ini sesuai dengan pernyataan Kotler (2002) dimana ketika merasakan kepuasan pelanggan akan menunjukkan perilaku tetap setia, Membeli produk yang ditawarkan, Merekomendasikan produk, Bersedia membayar lebih dan memberi masukan, ini berkaitan dengan Brand Loyalty.

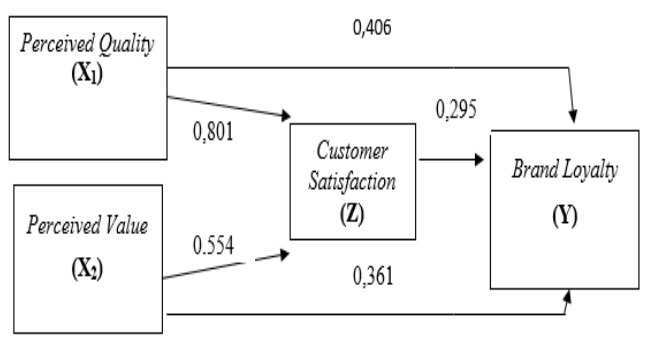

\section{Gambar 1 Hasil Analisis Jalur}

1. Menghitung Pengaruh Langsung (Direct Effect atau DE)

Pengaruh Variabel Perceived Quality (X1) terhadap Customer Satisfaction (Z)

DEzx $1=\mathrm{X} 1 \rightarrow \mathrm{Z}=0,801$

Pengaruh Variabel Perceived Value (X2) terhadap Customer Satisfaction (Z)

DEzx2 $=\mathrm{X} 2 \rightarrow \mathrm{Z}=0,554$

Pengaruh Variabel Perceived Quality (X1) terhadap Brand Loyalty (Y)

DEyx $1=\mathrm{X} 1 \rightarrow \mathrm{Y}=0,406$

Pengaruh Variabel Perceived Value (X2) terhadap Brand Loyalty (Y)

DEyx2 $=\mathrm{X} 2 \rightarrow \mathrm{Y}=0,361$

Pengaruh Variabel Customer Satisfaction (Z) terhadap Brand Loyalty (Y)

$\mathrm{DEyz}=\mathrm{Z} \rightarrow \mathrm{Y}=0,295$

2. Menghitung pengaruh tidak langsung (Indirect effect atau IE) Pengaruh Variabel Perceived Quality (X1) terhadap Brand Loyalty (Y)

melalui customer satisfaction $(\mathrm{Z})$ IEyzx $1 \rightarrow \mathrm{X} 1 \rightarrow \mathrm{Z} \quad \mathrm{Y}$
Indirect; $\mathrm{Y} \bullet \mathrm{X} 1 \rightarrow \mathrm{Z} \rightarrow \mathrm{Y}=$ $(0,801) \cdot(0,406)=0,325=32,5 \%$ Pengaruh Variabel Perceived Value (X2) terhadap Brand Loyalty (Y) melalui cutomer satisfation $(\mathrm{Z})$

IEyzx $2=\mathrm{X} 2 \rightarrow \mathrm{Z} \rightarrow \mathrm{Y}$

Indirect; $\mathrm{Y} \leftarrow \mathrm{X} 2 \rightarrow \mathrm{Z} \rightarrow \mathrm{Y}=$ $(0,361) \cdot(0,554)=0,199=19,9 \%$

3. Menghitung pengaruh total (Total effect atau TE). Pengaruh Variabel Perceived Quality (X1) terhadap Brand Loyalty $(\mathrm{Y})=$ pengaruh langsung variable $\mathrm{X} 1$ terhadap $\mathrm{Y}+$ pengaruh variabel $\mathrm{X} 1$ terhadap $\mathrm{Y}$ melalui $\mathrm{Z}$ TEyzx1 = DEyx1 + $\operatorname{IEyzx} 1=0,406+0,325=0,731=$ $73,1 \%$

Pengaruh Variabel Perceived Value (X2) terhadap Brand Loyalty (Y) = pengaruh langsung variable $\mathrm{X} 2$ terhadap $\mathrm{Y}+$ pengaruh variabel $\mathrm{X} 2$ terhadap $\mathrm{Y}$ melalui $\mathrm{Z}$

TEyzx $2=$ DEyx $2+$ IEyzx 2

$=0,361+0,199=0,560=56,0 \%$

Tabel 5 Hasil Analisis Koefisien Jalur

\begin{tabular}{|c|c|c|c|c|}
\hline \multicolumn{3}{|c|}{$\begin{array}{c}\text { Variabel } \\
\text { Terikat }\end{array}$} & $Y$ & \multirow[b]{2}{*}{ Jumlah } \\
\hline $\begin{array}{l}\text { Variabel } \\
\text { Bebas } \\
\end{array}$ & & $\begin{array}{l}\text { Pengaruh } \\
\text { Langsung }\end{array}$ & $\begin{array}{c}\text { Pengaruh } \\
\text { Tidak } \\
\text { Langsung }\end{array}$ & \\
\hline & $\mathrm{X} 1$ & $40,6 \%$ & $32,5 \%$ & $73,1 \%$ \\
\hline & $\mathrm{X} 2$ & $36,1 \%$ & $19,9 \%$ & $56,0 \%$ \\
\hline
\end{tabular}

Berdasarkan tabel 5 diatas, hasil

perhitungan koefisien jalur, terlihat bahwa total pengaruh Perceived Quality (X1) terhadap Brand Loyalty (Y) adalah $73,1 \%$ dengan rincian pengaruh langsung sebesar 40,6\% dan pengaruh tidak langsung sebesar $32,5 \%$. Total pengaruh Perceived Value (X2) terhadap Brand Loyalty (Y) adalah $56,0 \%$ dengan rincian pengaruh langsung sebesar $36,1 \%$ dan pengaruh tidak langsung sebesar 19,9\%. 
PENUTUP

Kesimpulan

Berdasarkan hasil analisis dan pembahasan yang diuraikan pada bab sebelumnya, maka dapat ditarik kesimpulan sebagai berikut:

1. Perceived quality dan Perceived Value berpengaruh secara langsung terhadap Brand Loyalty pelanggan J-Klin Beauty Jember

2. Perceived quality dan Perceived Value berpengaruh secara langsung dan tidak langsung terhadap Brand Loyalty melalui customer satisfaction pelanggan J-Klin Beauty Jember

3. Variabel Perceived quality merupakan variable dengan total pengaruh terbesar terhadap brand loyalty pelanggan J-Klin Beauty Jember

\section{Saran}

1. Untuk meningkatkan pengaruh Perceived quality terhadap brand loyalty, perusahaan dapat meningkatkan kualitas produk melalui inovasi baru dengan sentuhan teknologi

2. Untuk meningkatkan pengaruh Perceived Value terhadap Brand Loyalty perusahaan dapat memberikan pelatihan pada karyawan akan pelayanan prima terkait perawatan kecantikan dan komunikasi pelanggan

\section{DAFTAR PUSTAKA}

Beneke, Justin, Ryan Flynn, Tamsin Greig, dan Melissa Mukaiwa, (2013), "The influence of perceived product quality, relative price and risk on customer value and willingness to buy: a study of private label merchandise. Journal of Product \& Brand Management. 22(3): 218-228
Canon. (2008). Pemasaran dasar. salemba empat. Jakarta

Durianto,Sugiarto dan Tony Sitinjak, (2001). Strategi Menaklukkan Pasar Melalui. Riset Ekuitas dan Perilaku Merek, PT. Gramedia Pustaka

Dodds, William, B., Kent, B, Monroe, and Dhruv Grewal. (1991). Effects of Price, Brand, and Store Information on Buyers Product Evaluations, Journal of Marketing Research, 28: 307-19.

Kotler, Philip, (2002), Manajemen Pemasaran Edisi Millenium, Jilid I, Jakarta: Prehallindo.

Kotler, Philip. (2009). Manajemen Pemasaran. Jakarta : Erlangga.

Chi, Hain Kuang Yen, Huery Ren dan Yang, Ting Ya. (2009). The Impact of Brand Awareness on Consumer Purchase Intention: The Mediating Effect of Perceived Quality and Brand Loyalty The Journal of International Management Studies. 4 (1):135-144

Lupiyoadi, Rambat. (2001). Manajemen Pemasaran Jasa, Teori dan Praktek. Edisi Pertama. Jakarta: Salemba Empat

Mohammad. (2012). The Effect of Brand Trust and Perceived Value in Building Brand Loyalty. International Research Journal of Finance and Economics. 85.

Tjiptono, Fandy \& Chandra, Gregorius. (2011). Service, Quality and Satisfaction. Yogyakarta. Andi.

Badruddin, Syamsiah. (2009). Pengertian Pembangunan: Teori dan Indikator Pembangunan. Dipublikasikan dalam: http://profsyamsiah.wordperess.co $\mathrm{m} / 2009 / 03 / 19 /$ pengertianpembangunan/. diakses tanggal 13 Sepember 2014 
Parasuraman, A, Valarie A. Zeithaml, and Leonard L. Berry. (1988). SERVQUAL: A Multiple-Item Scale for Measuring Consumer Perceptions of Service Quality. Journal of Retailing. 64(1): 12-37

Tjiptono, Fandy, (2004). Manajemen Jasa, Yogyakarta: Andi Offset.

Wang, Ya-Hui \& Tsai, Cing-Fen. (2014). The Relationship Between Brand Image and Purchase Intention: Evidence From Award Winning Mutual Funds. The International Journal of Business and Finance Research. 8(2).

Gaspersz, Vincent, (2001), Total Quality Management. PT Gramedia Pustaka Utama, Jakarta Sugiyono. (2008). Metode Penelitian Kunatitatif Kualitatif dan R\&D. Bandung Alfabeta. 